\title{
Pengaruh Kualitas Produk, Harga dan Brand Image terhadap Keputusan Pembelian Produk Hand and Body Lotion Merek Citra (Studi Kasus pada Mahasiswa IAIN Salatiga)
}

\author{
Muhammad Syariful Anam \\ Institut Agama Islam Negeri (IAIN) Salatiga \\ syarifulanam2700@gmail.com
}

\author{
Dian Luthvita Nadila \\ Institut Agama Islam Negeri (IAIN) Salatiga \\ dianlvn16@gmail.com

\section{Tara Ayu Anindita} \\ Institut Agama Islam Negeri (IAIN) Salatiga \\ tarataa.psfebi@gmail.com
}

\section{Rina Rosia}

Institut Agama Islam Negeri (IAIN) Salatiga

rosia_rina@yahoo.com

\begin{abstract}
Abstrak Penelitian ini bertujuan untuk menganalisis pengaruh kualitas produk, harga dan brand image terhadap keputusan pembelian produk hand and body lotion merek Citra. Populasi dalam penelitian ini yaitu konsumen produk tersebut dari kalangan mahasiswi IAIN Salatiga. Karena jumlahnya belum teridentifikasi secara pasti, maka penentuan jumlah sampel dengan menggunakan rumus Cochrane dan diperoleh sampel sebanyak 96 orang. Metode analisis data yang digunakan adalah regresi linier berganda. Dari hasil penelitian, diperoleh kesimpulan bahwa secara parsial menunjukan kualitas produk berpengaruh positif dan signifikan terhadap keputusan pembelian, kemudian harga berpengaruh positif dan signifikan terhadap keputusan pembelian dan brand image juga berpengaruh positif dan signifikan terhadap keputusan pembelian. Sedangkan secara simultan kualitas produk, harga dan brand image berpengaruh signifikan terhadap keputusan pembelian produk hand and body lotion merek Citra.
\end{abstract}

Kata Kunci Kualitas Produk, Harga, Brand Image, Keputusan Pembelian, Hand and Body Lotion Citra

\section{PENDAHULUAN}

Saat ini industri kosmetik dunia mengalami perkembangan yang sangat pesat termasuk di Indonesia. Kemajuan dalam bidang ekonomi, sosial budaya dan teknologi membawa perubahan terhadap gaya hidup seseorang sehingga muncul berbagai produk perawatan kecantikan yang merupakan kebutuhan mendasar utamanya bagi kaum wanita. 
Perkembangan pada ketiga bidang tersebut menciptakan keketatan tingkat persaingan di dunia usaha perawatan kecantikan atau kosmetik, sehingga setiap perusahaan kosmetik harus terus meningkatkan inovasinya dalam memenuhi kebutuhan atau keinginan konsumen agar mampu bertahan di tengah persaingan dagang. Produsen kosmetik harus menentukan dengan tepat mengenai strategi pemasaran agar dapat bersaing dengan produsen kosmetik lainnya sehingga tujuan perusahaan dapat tercapai. Dalam penentuan strategi pemasaran, perusahaan harus dapat menganalisis berbagai perilaku konsumen agar produk yang mereka tawarkan sesuai dengan kebutuhan dan keinginan konsumen. Konsumen dalam kegiatannya membeli suatu produk kecantikan atau kosmetik dipengaruhi oleh berbagai faktor, diantaranya adalah kualitas produk, harga dan brand image (Indah et al., 2020).

Pada umumnya konsumen selalu dihadapkan dengan berbagai pertimbangan sebelum melakukan keputusan pembelian atas suatu produk, utamanya konsumen akan memperhatikan kualitas produk-produk yang akan mereka beli, semakin baik kualitas suatu produk kosmetik maka kecenderungan konsumen membeli produk tersebut juga meningkat. Setiap perusahaan produk kosmetik memiliki keunggulan dalam kualitas produk mereka masing-masing, dimana konsumen dapat memilih produk mana yang lebih unggul disesuaikan dengan kebutuhannya sehingga terciptalah keputusan dalam pembelian produk tersebut. Temuan yang mendukung diantaranya yaitu Kasanti et al. (2019), Wicaksono et al. (2019), Andriani et al. (2019) dan Sitanggang et al. (2020) yang pada hasil penelitiannya menyatakan bahwa terdapat pengaruh signifikan antara kualitas produk terhadap keputusan pembelian. Namun penelitian lain yang dilakukan Puspita et al. (2015) dan Sabrina et al. (2018) pada hasil uji hipotesisnya menunjukkan tidak ada pengaruh yang signifikan antara kualitas produk terhadap keputusan pembelian.

Selain kualitas produk, harga menjadi faktor terbesar dalam kegiatan pembelian suatu produk oleh kebanyakan konsumen. Harga menjadi salah satu variabel pemasaran yang fleksibel dan dapat dimainkan perusahaan. Tinggi dan rendahnya harga menjadi pertimbangan utama bagi konsumen sebelum memutuskan pembelian tehadap suatu produk, oleh sebab itu perusahaan harus bijak dalam penentuan harga produk yang dihasilkannya. Pada penelitian Istiyanto \& Nugroho (2017), Faroh (2017) serta Sitanggang et al. (2020) memperoleh hasil yakni harga (price) berpengaruh signifikan terhadap keputusan pembelian. Temuan penelitian tersebut bertolakbelakang dengan temuan penelitian yang dilakukan oleh Yazia (2014), Nasution et al. (2019) dan Andriani et al. (2019) bahwa variabel harga (price) tidak mempunyai pengaruh signifikan terhadap keputusan pembelian.

Faktor penentu keputusan pembelian lainnya yaitu brand image atau citra merek. Seluruh pandangan dan penilaian konsumen merupakan representasi dari keyakinan konsumen terhadap merek tersebut yang didapat melalui informasi serta pengalaman konsumen. Dapat diartikan bahwa citra positif yang telah terbangun dalam benak konsumen, akan membawa banyak kemungkinan keputusan konsumen untuk membeli produk tersebut. Penelitian yang dilakukan oleh Cahyani \& Sutrasmawati (2016), Habibah et al. (2018), Febriani \& Sudaryanto (2018) serta Fatmaningrum et al. (2020) menghasilkan temuan yakni terdapatnya pengaruh signifikan antara brand image terhadap keputusan pembelian. Sedangkan penelitian yang dilakukan oleh Istiyanto \& Nugroho (2017), Sabrina et al. (2018) dan Wicaksono et al. (2019) menyatakan bahwa 
variabel citra merek atau brand image tidak mempunyai pengaruh yang signifikan terhadap keputusan pembelian.

Pesatnya pertumbuhan pada industri kosmetik di Indonesia berimbas pada banyaknya pilihan yang ditawakan kepada konsumen dalam hal keputusan pembelian suatu merek produk kosmetik. Keputusan pembelian mempunyai arti sebuah tindakan seseorang secara langsung maupun tidak langsung berperan dalam usaha mendapatkan serta menggunakan produk yang ia dibutuhkan, dan juga bahan pertimbangan bagi perusahaan dalam pembentukan strategi pemasaran dimasa depan.

Tabel 1. Top Brand Index Tahun 2015-2019 Produk Hand and Body Lotion

\begin{tabular}{ccccccc}
\hline \multirow{2}{*}{ Merek } & \multicolumn{5}{c}{ Top Brand Index (\%) } & \multirow{2}{*}{ Top } \\
\cline { 2 - 5 } & $\mathbf{2 0 1 5}$ & $\mathbf{2 0 1 6}$ & $\mathbf{2 0 1 7}$ & $\mathbf{2 0 1 8}$ & $\mathbf{2 0 1 9}$ & \\
\hline Citra & 34,5 & 49,9 & 50,1 & 42,9 & 38,3 & 1 \\
Marina & 15,9 & 16,8 & 17,0 & 20,7 & 17,8 & 2 \\
Vaseline & 15,0 & 13,4 & 13,4 & 12,3 & 19,7 & 3 \\
Nivea & 5,5 & 3,6 & 3,3 & 4,8 & 6,2 & \\
\hline
\end{tabular}

Sumber: https://www.topbrand-award.com.

Produk kecantikan berupa lotion yang banyak diminati oleh masyarakat yaitu Hand and body lotion merek Citra yang di produksi oleh PT Unilever, produk Citra telah memiliki nama besar di Indonesia dan sudah dikenal diseluruh lapisan masyarakat. Pada Tabel Top Brand Index diatas dapat dilihat bahwa Citra dari tahun ke tahun berhasil menduduki peringkat pertama dalam urutan top brand index untuk nominasi produk hand and body lotion. Persentase produk Citra dari tahun 2015 sampai tahun 2019 mengalami pergerakan yang fluktuatif. Pada tahun 2015 hingga tahun 2017 persentase produk Citra mengalami peningkatan setiap tahunnya. Akan tetapi di tahun 2018 dan 2019 persentase produk Citra berturut-turut mengalami penurunan. Hal tersebut menunjukkan keputusan pembelian terhadap produk hand and body lotion merek Citra mengalami penurunan pada tahun 2018 hingga tahun 2019.

Konsumen terbesar dari produk hand and body lotion Citra tentunya adalah kaum hawa yang berada pada rentang usia remaja, dewasa hingga paruh baya. Mahasiswi merupakan salah satu konsumen terbesar, selain karena populasinya didominasi oleh mereka yang berusia remaja dan dewasa, sebagian besar dari mereka beranggapan bahwa menjaga tampilan agar senantiasa cantik dan bersih adalah suatu hal yang penting. Sehingga mahasiswi menjadi potential market bagi produk hand and body merek Citra. Mahasiswa perempuan Institut Agama Islam Negeri (IAIN) Salatiga merupakan salah satu potential market produk Citra dikarenakan banyak di kalangan mahasiwi yang menggunakan produk tersebut. Oleh sebab itu, peneliti meyakini bahwa mahasisiwi IAIN Salatiga merupakan subjek yang tepat dalam penelitian ini.

Angket atau kuesioner yang telah dilakukan pengisian oleh 96 mahasiswi IAIN Salatiga, lebih dari setengahnya menyatakan bahwa mereka memutuskan untuk melakukan pembelian terhadap produk hand and body lotion Citra dikarenakan mereka telah menaruh keyakinan dan kepercayaan bahwa produk tersebut mempunyai kualitas yang baik. Namun kurang dari setengah dari 96 orang mahasiswi menyatakan bahwa brand image produk hand and body lotion Citra tidak memberikan hasil sesuai dengan apa yang diklaimkan selama ini, karena produk tersebut tidak berfungsi secara maksimal 
pada saat penggunaan seperti yang telah diiklankan walaupun produk memiliki harga yang relatif terjangkau dibandingkan produk lotion merek lainnya. Kondisi yang terjadi secara nyata ini kemudian melahirkan sebuah pertanyaan apakah terdapat pengaruh dari variabel kualitas produk, harga dan brand image terhadap keputusan pembelian, atau apakah variabel-variabel tersebut menjadi penyebab tingkat indeks merek produk hand and body lotion merek Citra mengalami penurunan pada tahun 2018 dan 2019.

Berdasarkan pemikiran, penelitian terdahulu serta latar belakang tersebut, penulis bermaksud melakukan penelitian yang berjudul pengaruh variabel kualitas produk, harga, dan brand image terhadap keputusan pembelian produk hand and body lotion merek Citra oleh para konsumen, dimana studi kasus pada penelitian ini adalah mahasiwi IAIN Salatiga.

\section{LANDASAN TEORI}

\subsection{Kualitas Produk}

Kualitas produk merupakan sebuah ciri khas yang dimiliki oleh suatu produk dimana berkontribusi terhadap kemampuan memenuhi permintaan yang ditentukan. Suatu produk yang dibuat oleh perusahaan ditawarkan ke pasar dengan tujuan mendapatkan atensi, keahlian, kegunaan atau konsumsi dengan melihat kebutuhan atau keinginan konsumen (Razak et al., 2016). Kualitas produk merupakan sebuah feedback yang didapat dari konsumen bukan dari perusahaan. Maka, setelah konsumen membeli produk tersebut akan ada faktor-faktor yang akan memengaruhi dari kualitas produk tersebut yakni kualitas produk yang diharapkan oleh konsumen dan yang dirasakan setelah konsumen menggunakan produk tersebut. Menurut Garvin dalam Tjiptono (2008) kualitas produk mempunyai indikator yang meliputi kinerja, ciri-ciri/keistimewaan, kesesuaian dengan spesifikasi, keandalan, daya tahan produk dan estetika.

\subsection{Harga}

Harga merupakan nilai yang dihasilkan oleh konsumen yang mana mengubah manfaat dari kepemilikan atau penggunaan menjadi suatu produk atau layanan. Hasil dari salah satu elemen yang berasal dari harga adalah pendapatan. Meningkatnya sebuah penjualan, keuntungan dan share pasar yang dihasilkan dipengaruhi oleh harga. Ketika harga meningkat dapat mengurangi permintaan dari suatu produk karena harga merupakan elemen yang penting dalam suatu transaksi jual beli yang berpengaruh langsung terhadap konsumen. Dimana harga merupakan bagian dari suatu elemen yang penting untuk ditetapkan ketika memasuki pasar dengan tingkat competitive yang sangat tinggi (Hustić \& Gregurec, 2015).

Salah satu strategi bersaing perusahaan ialah melalui penetapan harga produk, penetapan harga yang dilakukan harus sesuai dengan cara yang dipilih oleh perusahaan dalam menempatkan posisi relatifnya dalam persaingan (Shinta, 2011). Penentuan harga dibatasi adanya permintaan, persaingan, dan biaya. Dimana harga akan bergerak fluktuasi sesuai dengan ruang gerak persaingan yang ada di pasar. Perubahan yang terjadi tidak akan melebihi dari batas harga tertinggi, pun tidak akan lebih rendah dari harga yang ditentukan oleh produsen. Menurut Kotler \& Keller (2009) terdapat beberapa indikator dalam penetapan harga bagi konsumen yakni keterjangkauan harga, daya saing harga dan kesesuaian harga dengan manfaat dari produk. 


\subsection{Brand Image}

Brand diartikan sebagai gambar yang dapat diingat oleh publik, menciptakan sebuah brand yang positif, relevan dan mudah diingat oleh konsumen (Novansa \& Ali, 2017). Brand image juga dapat diartikan sebagai persepsi konsumen yang melibatkan rasional ataupun emosi sebagai wujud perhatian terhadap merek tertentu. Brand image yang tercipta positif akan memengaruhi program pemasaran yang mungkin disukai oleh konsumen dan akan menjadi sebuah keunikan untuk menarik konsumen (Fianto et al., 2014).

Selain itu, brand image merupakan sebuah aset dan kewajiban, yakni secara bersamaan dapat meningkatkan atau mengurangi nilai dengan tersedianya produk atau pelayanan kepada konsumen. Dengan memiliki atribut dan manfaat yang dibawa maka karakteristik yang telah melekat pada brand dan hal itu menjadi berbeda dari pesaingpesaing lain yang ada (Mulyono, 2016). Hal itu menjadikan persepsi konsumen yang dipengaruhi oleh karakteristik kuat produk tersebut akan menimbulkan citra merek tersebut lebih tinggi di mata konsumen (Sallam, 2016). Menurut Biel (1992) dalam Li et al. (2011) brand image dibentuk oleh beberapa indikator yaitu citra perusahaan, citra pengguna dan citra produk.

\subsection{Keputusan Pembelian}

Dalam melakukan pembelian sebuah produk, konsumen tentu akan memikirkan terlebih dahulu sebelum memutuskan untuk membeli atau tidaknya suatu produk (Novansa \& Ali, 2017). Dalam melakukan keputusan pembelian, konsumen akan melalui beberapa tahapan, antara lain; pengenalan terhadap kebutuhan, pencarian informasi tentang produk, evaluasi alternatif sebelum pembelian, keputusan pembelian dan perilaku setelah pembelian (Kotler \& Armstrong, 2008). Indikator dalam keputusan pembelian yaitu kemantapan pada sebuah produk, kebiasaan dalam membeli produk dan melakukan pembelian ulang.

\subsection{Perumusan Hipotesis}

Dari landasan teori di atas maka dirumuskan hipotesis dalam penelitian ini, yaitu:

H1 : Kualitas produk memiliki pengaruh signifikan terhadap keputusan pembelian produk hand and body lotion merek Citra.

$\mathrm{H} 2$ : Harga memiliki pengaruh signifikan terhadap keputusan pembelian produk hand and body lotion merek Citra.

H3 : Brand image memiliki pengaruh signifikan terhadap keputusan pembelian produk hand and body lotion merek Citra.

H4 : Kualitas produk, harga dan brand image memiliki pengaruh signifikan terhadap keputusan pembelian produk hand and body lotion merek Citra.

\subsection{Kerangka Pemikiran}

Berdasarkan hipotesis yang diajukan, maka dapat digambarkan model kerangka pemikiran penelitiannya sebagai berikut: 


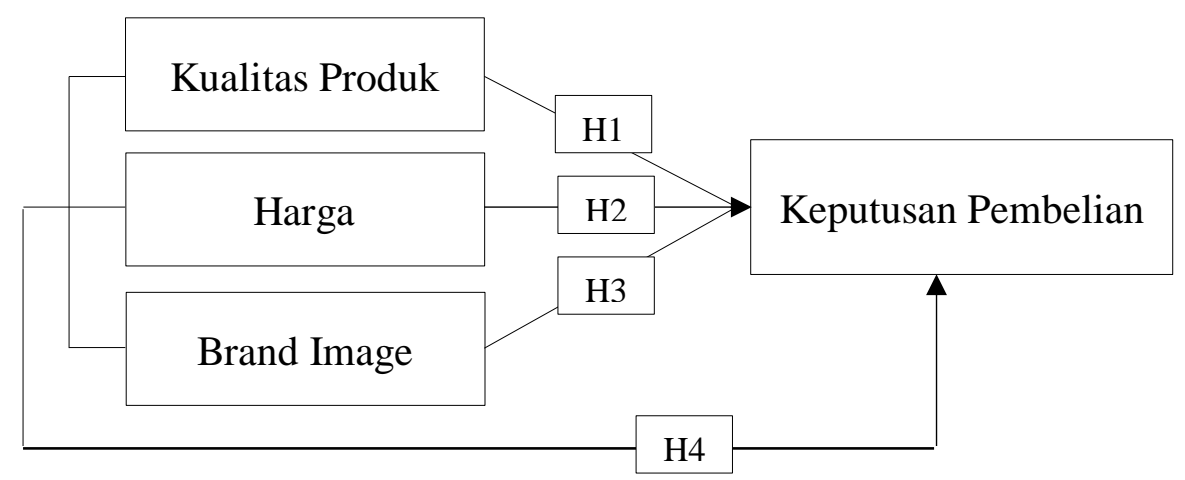

Gambar 1. Kerangka Pemikiran

Sumber: Diolah penulis, 2020.

\section{METODOLOGI PENELITIAN}

\subsection{Jenis Penelitian}

Penelitian ini bermaksud untuk menganalisis variabel kualitas produk, harga dan brand image (citra merek) terhadap keputusan pembelian produk hand and body lotion merek Citra. Penelitian ini merupakan penelitian kuantitatif dengan menggunakan data primer sebagai data utama yang diperoleh dari hasil penyebaran angket (kuesioner) dan juga menggunakan data sekunder untuk memperkuat argumentasi yang diperoleh dari situs website atau sumber-sumber yang telah ada. Subjek yang dipilih oleh peneliti adalah mahasiswi IAIN Salatiga.

\subsection{Populasi dan Sampel}

Populasi merupakan objek/subjek dari wilayah generalisasi yang ditetapkan oleh peneliti dengan kuantitas dan sifat tertentu untuk dikaji dan kemudian ditarik suatu kesimpulan (Sugiyono, 2019). Populasi dalam penelitian ini yaitu konsumen produk hand and body lotion merek Citra dari kalangan mahasiswi IAIN Salatiga yang jumlahnya tidak diketahui secara pasti. Maka dari itu untuk menentukan ukuran sampel menurut Sugiyono (2019) dapat menggunakan rumus Cochrane. Secara matematis dituliskan sebagai berikut:

$\mathrm{n}=\frac{z^{2} p q}{\mathrm{e}^{2}}=\frac{(1,96)^{2}(0,5)(0,5)}{(0,1)^{2}}=96,04$

\section{Keterangan:}

$\mathrm{n} \quad=$ Jumlah sampel

$\mathrm{z} \quad=$ Harga dalam kurve normal untuk simpangan 5\%, dengan nilai 1,96

$\mathrm{p} \quad=$ Peluang benar $(50 \%)$

$\mathrm{q} \quad=$ Peluang salah $(50 \%)$

e $\quad=$ Sampling error $(10 \%)$

Dari hasil kalkulasi diperoleh jumlah sampel sebanyak 96,04 dibulatkan menjadi 96 responden. Selanjutnya sampel ditentukan dengan metode Nonprobability Sampling dengan menggunakan teknik Sampling Purposive, yaitu teknik yang digunakan untuk 
menetapkan sampel dengan pertimbangan tertentu (Sugiyono, 2019). Teknik ini dilakukan dengan cara membagikan link kuisioner yang dibuat menggunakan google form dengan disertai keterangan sebagai berikut:

a. Mahasiswi S1 IAIN Salatiga tahun angkatan 2016, 2017, 2018 dan 2019.

b. Pernah melakukan pembelian produk hand and body lotion merek Citra minimal satu kali.

\subsection{Teknik Pengumpulan Data}

Teknik pengumpulan data dilakukan dengan menggunakan dua cara yaitu penyebaran kuisioner (angket) dan studi dokumentasi. Kuisioner dibagikan kepada 96 responden melalui WhatsApp grup. Selanjutnya, data dokumentasi dikumpulkan dari literatur-literatur yang telah ada seperti dari buku, artikel penelitian, dan website yang kredibel.

\subsection{Metode Analisis Data}

Analisis atau pengujian terhadap data dilakukan melalui beberapa tahap. Tahap awal yaitu uji validitas dan reliabilitas. Setelah dinyatakan valid dan reliabel, tahap kedua yaitu uji asumsi klasik yang terdiri dari uji multikolinieritas, uji heteroskedastisitas dan uji normalitas. Tahap ketiga ialah analisis regresi linier berganda. Regresi linier berganda merupakan metode untuk menguji pengaruh lebih dari satu variabel independen terhadap variabel dependen (Ghozali, 2018). Secara matematis persamaan regresinya sebagai berikut:

$$
\mathrm{Y}=\beta_{0}+\beta_{1} X_{1}+\beta_{2} X_{2}+\ldots \ldots \ldots \beta_{n} X_{n}+e
$$

Rumus tersebut kemudian ditransformasikan ke dalam penelitian ini, sehingga menjadi:

Dimana:

$$
\mathrm{KP}=\beta_{0}+\beta_{1} \mathrm{KLP}+\beta_{2} \mathrm{HRG}+\beta_{3} \mathrm{BI}+\mathrm{e}
$$

\begin{tabular}{|c|c|}
\hline $\mathrm{KP}$ & $=$ Keputusan pembelian \\
\hline$\beta_{0}$ & $=$ Kostanta \\
\hline$\beta_{1} \beta_{2} \beta_{3}$ & $=$ Koefisien \\
\hline KLP & $=$ Kualitas produk \\
\hline HRG & $=$ Harga \\
\hline BI & $=$ Brand image \\
\hline $\mathrm{e}$ & $=$ Error term \\
\hline
\end{tabular}

Tahap terakhir adalah melakukan pengujian terhadap hipotesis yang telah dirumuskan dan diajukan baik pengaruh secara parsial maupun simultan.

\section{HASIL PENELITIAN}

\subsection{Hasil Uji Validitas}

Uji validitas dimaksudkan untuk mendeteksi instrumen (kuesioner) yang digunakan sebagai pengumpulan data apakah telah valid atau tidak yaitu dengan cara mengkorelasikan skor jawaban dari setiap responden dengan skor total tiap-tiap variabel (Yuliardi \& Nuraeni, 2017). Kuesioner dapat dikatakan valid apabila pernyataan dalam kuesioner memiliki $r_{\text {hitung }}>\mathrm{r}_{\text {tabel. }}$. Taraf signifikansi yang digunakan adalah $5 \%$ dengan degree of freedom $(\mathrm{df})=\mathrm{n}-2$. Karena jumlah sampel $(\mathrm{n})$ telah diketahui sebanyak 96 responden, maka besarnya $\mathrm{df}$ adalah 96-2 $=94$, sehingga diperoleh nilai $r_{\text {tabel }}$ sebesar 
0,201 sedangkan nilai $\mathrm{r}_{\text {hitung }}$ dapat diketahui dari Correlated Item - Total Correlation. Berikut tabel hasil pengujiannya:

Tabel 2. Uji Validitas

\begin{tabular}{|c|c|c|c|c|}
\hline Variabel & Indikator & $\mathbf{r}_{\text {hitung }}$ & $\mathbf{r}_{\text {tabel }}$ & Keterangan \\
\hline \multirow{7}{*}{ Kualitas Produk $\left(\mathrm{X}_{1}\right)$} & KLP1 & 0,674 & \multirow{7}{*}{0,201} & Valid \\
\hline & KLP2 & 0,701 & & Valid \\
\hline & KLP3 & 0,373 & & Valid \\
\hline & KLP4 & 0,699 & & Valid \\
\hline & KLP5 & 0,631 & & Valid \\
\hline & KLP6 & 0,753 & & Valid \\
\hline & KLP7 & 0,671 & & Valid \\
\hline \multirow{7}{*}{$\operatorname{Harga}\left(\mathrm{X}_{2}\right)$} & HRG1 & 0,545 & \multirow{7}{*}{0,201} & Valid \\
\hline & HRG2 & 0,690 & & Valid \\
\hline & HRG3 & 0,765 & & Valid \\
\hline & HRG4 & 0,617 & & Valid \\
\hline & HRG5 & 0,413 & & Valid \\
\hline & HRG6 & 0,691 & & Valid \\
\hline & HRG7 & 0,687 & & Valid \\
\hline \multirow{7}{*}{ Brand Image $\left(\mathrm{X}_{3}\right)$} & BI1 & 0,702 & \multirow{7}{*}{0,201} & Valid \\
\hline & $\mathrm{BI} 2$ & 0,625 & & Valid \\
\hline & $\mathrm{BI} 3$ & 0,688 & & Valid \\
\hline & BI4 & 0,728 & & Valid \\
\hline & BI5 & 0,757 & & Valid \\
\hline & BI6 & 0,704 & & Valid \\
\hline & BI7 & 0,763 & & Valid \\
\hline \multirow{7}{*}{$\begin{array}{l}\text { Keputusan Pembelian } \\
\text { (Y) }\end{array}$} & KP1 & 0,840 & \multirow{7}{*}{0,201} & Valid \\
\hline & KP2 & 0,898 & & Valid \\
\hline & KP3 & 0,902 & & Valid \\
\hline & KP4 & 0,828 & & Valid \\
\hline & KP5 & 0,899 & & Valid \\
\hline & KP6 & 0,844 & & Valid \\
\hline & KP7 & 0,844 & & Valid \\
\hline
\end{tabular}

Sumber: Data primer diolah, 2020.

Berdasarkan tabel 2, mengindikasikan bahwa semua item pertanyaan yang diajukan dari keempat variabel yang berjumlah 28 item, memiliki $r_{\text {hitung }}>0,201$. Dengan demikian seluruh item pernyataan dalam penelitian telah valid dan dapat digunakan untuk dianalisis lebih lanjut. Selanjutnya yaitu melakukan uji reliabilitas terhadap item pernyataan yang telah dinyatakan valid.

\subsection{Hasil Uji Reliabilitas}

Item yang telah dinyatakan valid, selanjutnya dilakukan uji reliabilitas. Hasil pengujiannya sebagai berikut: 
Tabel 3. Uji Reliabilitas

\begin{tabular}{lccc}
\hline \multicolumn{1}{c}{ Variabel } & $\begin{array}{c}\text { Cronbach's } \\
\text { Alpha }\end{array}$ & Koefisien & Keterangan \\
\hline Kualitas Produk $\left(\mathrm{X}_{1}\right)$ & 0,770 & & Reliabel \\
Harga $\left(\mathrm{X}_{2}\right)$ & 0,741 & \multirow{2}{*}{0.70} & Reliabel \\
Brand Image $\left(\mathrm{X}_{3}\right)$ & 0,825 & & Reliabel \\
Keputusan Pembelian $(\mathrm{Y})$ & 0,944 & & Reliabel \\
\hline
\end{tabular}

Sumber: Data primer diolah, 2020.

Suatu variabel dapat dikatakan reliabel apabila nilai dari Cronbach's Alpha $>0,70$ (Nunnally, 1994 dalam Ghozali, 2018). Berdasarkan tabel 3, seluruh variabel dalam penelitian memiliki skor Cronbach's Alpha >0,70. Karena hasil pengujian telah sesuai dengan ketentuan dan teori statistik, maka data telah reliabel dan dapat digunakan untuk uji-uji berikutnya.

\subsection{Uji Asumsi Klasik}

\section{Hasil Uji Multikolinieritas}

Tabel 4. Uji Multikolinieritas

\begin{tabular}{llcc}
\hline & & \multicolumn{2}{c}{ Collinearity Statistics } \\
\cline { 3 - 4 } Model & & Tolerance & VIF \\
\hline 1 & (Constant) & & \\
& Kualitas Produk & 0,462 & 2,162 \\
& Harga & 0,528 & 1,895 \\
& Brand Image & 0,470 & 2,130 \\
\hline
\end{tabular}

Sumber: Data primer diolah, 2020.

Menurut Sudarmanto (2005) dalam Rusman (2015) uji multikolinieritas digunakan untuk membuktikan apakah antara variabel bebas satu dengan lainnya memiliki korelasi linier. Dalam hal ini, peneliti menggunakan cara untuk uji multikolinieritas dengan melihat skor Tolerance dan VIF. Berdasarkan hasil pengujian seperti pada tabel 4, tidak ada satu pun variabel bebas yang memiliki nilai Tolerance $<0,10$. Kemudian skor VIF juga memperlihatkan hasil yang sama bahwa tidak terdapat satu pun variabel bebas yang memiliki nilai VIF > 10. Dengan demikian dapat disimpulkan bahwa variabel bebas dalam model tidak terdapat korelasi linier antara satu dengan lainnya, atau terbebas dari gejala multikolinieritas.

\section{Hasil Uji Heteroskedastisitas}

Tabel 5. Uji Heteroskedastisitas Metode Park

\begin{tabular}{llcc}
\hline Model & & $\mathrm{t}$ & Sig. \\
\hline 1 & (Constant) & 1,703 & 0,092 \\
& Kualitas Produk & 0,516 & 0,607 \\
& Harga & $-1,799$ & 0,075 \\
& Brand Image & 0,154 & 0,878 \\
\hline
\end{tabular}

Sumber: Data primer diolah, 2020. 
Uji heteroskedastisitas bermaksud untuk menganalisis model regresi apakah terjadi ketidaksamaan variance dari residual satu pengamatan ke pengamatan lain (Ghozali, 2018). Tabel 5 adalah hasil dari uji heteroskedastisitas dengan menggunakan metode Park. Agar tidak terjadi gejala heteroskedastisitas, skor signifikansi harus $>$ alpha $(0,05)$. Hasil pengujian menunjukkan nilai signifikansi variabel kualitas produk 0,607 >0,05, variabel harga 0,075 >0,05, variabel brand image 0,878 >0,05. Oleh karena itu, model regresi dapat dikatakan tidak terjadi masalah heteroskedastisitas.

\section{Hasil Uji Normalitas}

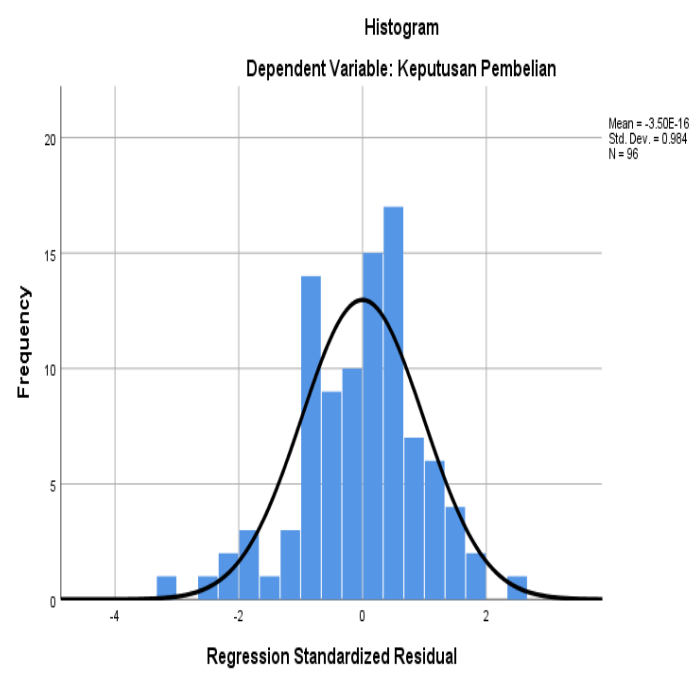

Gambar 2. Histogram

Sumber: Data primer diolah, 2020.

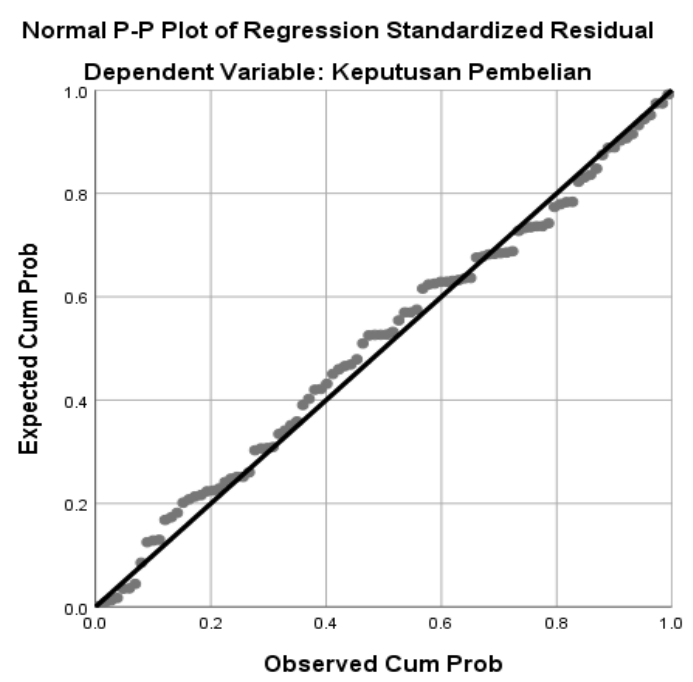

Gambar 3. Normal P-P Plot

Sumber: Data primer diolah, 2020.

Tabel 6. Uji Kolmogorov-Smirnov

\begin{tabular}{llr}
\hline & & Unstandardized Residual \\
\hline N & & 96 \\
\cline { 2 - 3 } Mormal Parameters & Mean & 0,0000000 \\
& Std. Deviation & 3,43453827 \\
& Absolute & 0,057 \\
Test Statistic & Positive & 0,046 \\
Asymp. Sig. (2-tailed) & Negative & $-0,057$ \\
& & 0,057 \\
Sumberences & & 0,200 \\
\hline
\end{tabular}

Sumber: Data primer diolah, 2020.

Pengujian normalitas dimaksudkan untuk menganalisis apakah standarisasi nilai residual dalam model telah terdistribusi secara normal atau tidak. Skor residual telah terdistribusi normal apabila standarisasi dari nilai residualnya mayoritas mendekati ratarata (Suliyanto, 2011). Dari hasil uji normalitas seperti pada gambar 2 (Histogram) 
menampilkan output seperti gambar lonceng yang berarti membentuk pola distribusi normal. Kemudian pada gambar 3 (Normal Probability Plot), titik-titik menyebar mengikuti arah garis diagonalnya. Analisis grafik (histogram dan Normal Probability Plot) memiliki kelemahan dan terlalu subjektif, maka dari itu dilakukan juga pengujian secara statistik dengan cara analisis uji K-S (Kolmogorov-Smirnov). Model regresi terdistribusi normal apabila skor Sig. > tingkat alpha (Suliyanto, 2011). Dari hasil pengujian seperti pada tabel 6 , diperoleh skor signifikansi $0,200>0,05$. Dengan demikian, data dalam model telah terdistribusi normal.

\subsection{Hasil Analisis Regresi Berganda}

Tabel 7. Analisis Regresi Linier Berganda

\begin{tabular}{|c|c|c|c|c|c|c|}
\hline \multirow[b]{2}{*}{ Model } & & \multicolumn{2}{|c|}{$\begin{array}{c}\text { Unstandardized } \\
\text { Coefficients }\end{array}$} & \multirow{2}{*}{$\begin{array}{c}\text { Standardized } \\
\text { Coefficients }\end{array}$} & \multirow[b]{2}{*}{$t$} & \multirow[b]{2}{*}{ Sig. } \\
\hline & & $\mathrm{B}$ & Std. Error & & & \\
\hline \multirow[t]{4}{*}{1} & (Constant) & $-17,484$ & 3,100 & & -5.640 & 0,000 \\
\hline & Kualitas Produk & 0,521 & 0,158 & 0,290 & 3,299 & 0,001 \\
\hline & Harga & 0,465 & 0,125 & 0,307 & 3,732 & 0,000 \\
\hline & Brand Image & 0,523 & 0,134 & 0,340 & 3,894 & 0,000 \\
\hline
\end{tabular}

Sumber: Data primer diolah, 2020.

Tabel 7 merupakan hasil analisis regresi linier berganda, dapat dilihat pada kolom $\mathrm{B}$, sehingga persamaan regresinya sebagai berikut:

$$
\mathrm{KP}=-17,484+0,521 \mathrm{KLP}+0,465 \mathrm{HRG}+0,523 \mathrm{BI}
$$

Dari persamaan tersebut diperoleh nilai koefisien $\beta_{1}$ (Kualitas Produk) sebesar 0,521 . Nilai koefisien menunjukan pengaruh yang positif antara kualitas produk terhadap keputusan pembelian. Artinya, jika harga dan brand image bernilai konstan, maka keputusan pembelian akan mengalami peningkatan sebesar 0,521.

Selanjutnya, dari persamaan regresi diperoleh nilai koefisien $\beta_{2}$ (Harga) sebesar 0,465. Nilai tersebut juga menunjukan pengaruh positif antara harga terhadap keputusan pembelian. Artinya, apabila kualitas produk dan brand image bernilai konstan, maka keputusan pembelian akan mengalami peningkatan sebesar 0,465.

Ketiga, dari persamaan regresi diperoleh nilai koefisien $\beta_{3}$ (Brand Image) sebesar 0,523. Nilai koefisien tersebut memiliki pengaruh positif antara brand image terhadap keputusan pembelian. Artinya, jika kualitas produk dan harga memiliki nilai konstan, maka keputusan pembelian akan mengalami peningkatan sebesar 0,523. 


\subsection{Hasil Uji Hipotesis}

Tabel 8. Uji Hipotesis

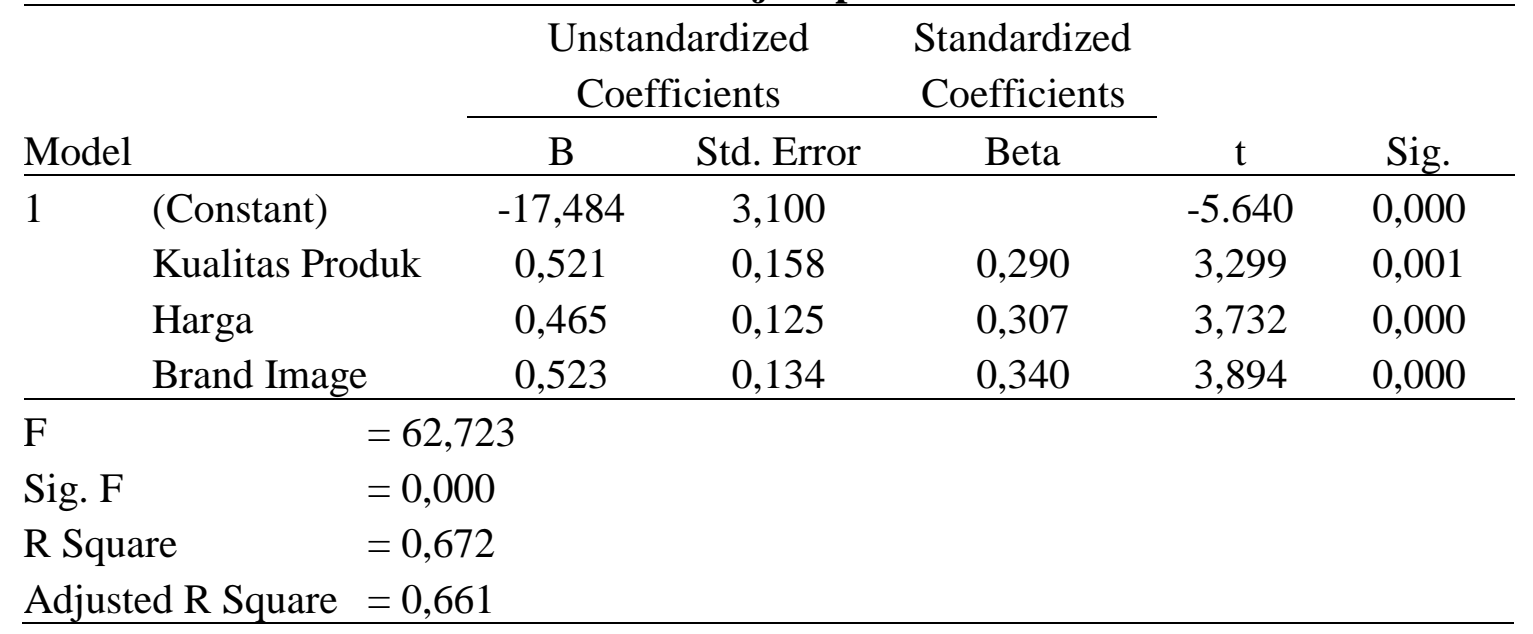

Sumber: Data primer diolah, 2020.

Pengujian hipotesis dibagi ke dalam dua kelompok, yaitu hipotesis secara individual (parsial) dan hipotesis secara bersamaan (simultan). Hipotesis individual dilakukan dengan menggunakan uji t, sedangkan hipotesis simultan dilakukan dengan menggunakan uji $\mathrm{F}$.

Berdasarkan tabel 8, variabel kualitas produk $\left(\mathrm{X}_{1}\right)$ diperoleh nilai Sig. 0,001<0,05. Sehingga dapat disimpulkan bahwa kualitas produk secara individual (parsial) memiliki pengaruh signifikan terhadap keputusan pembelian. Oleh karena itu, hipotesis pertama (H1) diterima.

Berikutnya, variabel harga $\left(X_{2}\right)$ diperoleh nilai Sig. $0,000<0,05$. Sehingga dapat dikatakan bahwa harga memiliki pengaruh yang signifikan terhadap keputusan pembelian. Oleh karena itu, hipotesis kedua (H2) diterima.

Ketiga, variabel brand image $\left(\mathrm{X}_{3}\right)$ diperoleh nilai Sig. $0,000<0,05$. Sehingga dapat dikatakan bahwa brand image memiliki pengaruh signifikan terhadap keputusan pembelian. Oleh karena itu, hipotesis ketiga (H3) diterima.

Hipotesis keempat yaitu berkenaan dengan pengaruh simultan dari ketiga variabel bebas (kualitas produk, harga dan brand image) terhadap variabel terikat (keputusan pembelian). Berdasarkan hasil pengujian diperoleh nilai Sig. 0,000 $<0,05$. Sehingga, secara simultan variabel independen berpengaruh signifikan terhadap keputusan pembelian. Oleh karena itu, hipotesis keempat (H4) diterima.

Kemudian, masih dalam tabel yang sama diperoleh juga nilai dari Adjusted $R$ Square sebesar 0,661 atau 66,1\%, yang memiliki arti bahwa variasi dari ketiga variabel bebas mampu mempengaruhi variabel dependen sebesar $66,1 \%$. Sedangkan sisanya sebesar 0,339 atau 33,9\% dipengaruhi oleh variabel diluar model.

\subsection{Pembahasan}

Dari hasil analisis data yang telah dilakukan, ditemukan bahwa kualitas produk berpengaruh positif dan signifikan terhadap keputusan pembelian produk hand and body lotion merek Citra. Temuan ini mengindikasikan bahwa konsumen dalam melakukan pembelian akan memperhatikan kualitas dari produk tersebut, semakin baik kualitasnya 
maka semakin besar keputusan pembelian yang akan dilakukan oleh konsumen. Hasil ini mendukung temuan empiris yang dilakukan oleh Amron (2018), Sarjita (2019) dan Alfred (2013) yang juga memperoleh hasil bahwa kualitas produk berpengaruh positif dan signifikan terhadap keputusan pembelian. Akan tetapi, penelitian ini bertentangan dengan Amelisa et al. (2016) dan Supriyadi et al. (2016) yang berargumen bahwa kualitas produk tidak memiliki pengaruh terhadap keputusan pembelian.

Hasil pengujian berikutnya juga menemukan bahwa harga berpengaruh positif dan signifikan terhadap keputusan pembelian produk hand and body lotion merek Citra. Berdasarkan analisis regresi, skor koefisien dari variabel harga merupakan nilai yang paling rendah dibandingkan dua variabel lainnya, artinya bahwa harga yang ditetapkan oleh produsen terhadap produk tersebut tidak terlalu sensitif atau masih terjangkau oleh konsumen. Hasil ini kemudian mendukung temuan empiris lainnya yang dilakukan oleh Widjayanti \& Suprihhadi (2018) dan Novansa \& Ali (2017) yang mengungkapkan bahwa harga berpengaruh positif dan signifikan terhadap keputusan pembelian. Akan tetapi, hasil temuan ini bertentangan dengan Deisy et al. (2018) dan Mandey (2013) yang menyatakan harga tidak berpengaruh terhadap keputusan pembelian.

Analisis selanjutnya juga berhasil membuktikan bahwa brand image berpengaruh positif dan signifikan terhadap keputusan pembelian produk hand and body lotion merek Citra. Namun dari hasil uji regresi, variabel brand image memiliki nilai koefisien paling tinggi di antara dua variabel lainnya, artinya konsumen sangat sensitif terhadap persepsi dari brand image produk tersebut, sehingga bisa saja penurunan persentase dari tahun 2018-2019 dari produk hand and body lotion merek Citra dipengaruhi oleh brand image. Akan tetapi, kondisi tersebut masih dapat diatasi oleh produsen, karena memang produsen yang memproduksi produk tersebut memiliki citra yang baik dibenak masyarakat, sehingga sebagian besar masyarakat masih memiliki tingkat kepercayaan yang tinggi terhadap produsen. Hasil ini mendukung temuan empiris yang dilakukan oleh Sudaryanto et al. (2019) dan Ambolau et al. (2015) yang mengatakan bahwa brand image berpengaruh positif dan signifikan terhadap keputusan pembelian. Akan tetapi, hasil temuan ini tidak selaras dengan Wicaksono et al. (2019) dan Lubis \& Hidayat (2017) yang berargumen bahwa brand image tidak memiliki pengaruh terhadap keputusan pembelian.

Terakhir, penelitian ini berhasil membuktikan bahwa secara simultan ketiga variabel independen berpengaruh signifikan terhadap keputusan pembelian produk hand and body lotion merek Citra. Temuan ini dapat dijadikan pertimbangan bagi produsen terkait peningkatan kualitas produk, penetapan harga dan pengembangan brand image agar tetap diminati oleh masyarakat terhadap produk hand and body lotion merek Citra. Hasil temuan ini juga menambahkan temuan-temuan empiris lainnya seperti yang dilakukan oleh Indah et al. (2020), Mahmudah \& Tiarawati (2014), Fatmawati \& Soliha (2017) dan Hendro \& Hidayat (2018) yang menyatakan bahwa kualitas produk, harga dan brand image berpengaruh secara signifikan terhadap keputusan pembelian.

\section{KESIMPULAN}

Berdasarkan analisis yang telah dilakukan dapat ditarik beberapa kesimpulan, pertama kualitas produk, harga dan brand image secara individual (parsial) berpengaruh positif dan signifikan terhadap keputusan pembelian. Kedua, variabel kualitas produk, harga dan brand image secara serempak (simultan) memiliki pengaruh yang signifikan 
terhadap keputusan pembelian produk hand and body lotion merek Citra. Kemudian, brand image terindetifikasi sebagai variabel yang paling dominan terhadap keputusan pembelian dibandingkan variabel lain dalam penelitian ini.Penelitian ini juga memberikan sejumlah rekomendasi, pertama produsen dari produk hand and body lotion merek Citra diharapkan terus berinovasi dalam meningkatkan kualitas produknya agar masyarakat selalu memperoleh kenyamanan dari produk yang digunakannya. Kedua, penetapan harga produk agar terus disesuaikan dengan kemampuan daya beli masyarakat terutama kelompok menengah ke bawah. Ketiga, brand image harus terus ditingkatkan agar selalu mendapatkan citra yang baik dibenak masyarakat, cara yang mungkin dapat dilakukan adalah memberikan keunggulan baru dari produk hand and body lotion merek Citra sehingga dapat terus bersaing dengan produk-produk sejenis.

\section{DAFTAR PUSTAKA}

Alfred, O. (2013). Influences of Price And Quality On Consumer Purchase Of Mobile Phone In The Kumasi Metropolis In Ghana A Comparative Study. European Journal of Business and Management, 5(1), 179-199.

Ambolau, M. A. P., Kusumawati, A., \& Mawardi, M. K. (2015). The Influence Of Brand Awareness and Brand Image On Purchase Decision (Study on AQUA Consumers in Administrative Science Faculty Brawijaya University Class Of 2013). Jurnal Administrasi Bisnis, 2(2), 1-8.

Amelisa, L., Yonaldi, S., \& Mayasari, H. (2016). Analisis Pengaruh Kualitas Produk dan Harga terhadap Keputusan Pembelian Gula Tebu. Jurnal Manajemen Dan Kewirausahaan, 7(3), 1-13.

Amron, A. (2018). Effects of Product Quality, Price, and Brand Image on the Buying Decision of City Car Product. Archives of Business Research, 6(4), 1-8.

Andriani, W., Abdurrahman, \& Sari, P. R. K. (2019). Pengaruh Kualitas Produk, Harga, dan Promosi terhadap Keputusan Pembelian Air Mineral Dalam Kemasan Merek Dharma (Studi Kasus pada Konsumen CV. Bahana Tirta Alam Maritim di Kab. Sumbawa Besar). Jurnal Manajemen Dan Bisnis, 2(1), 1-7.

Cahyani, K. I., \& Sutrasmawati, R. E. (2016). Pengaruh Brand Awareness dan Brand Image terhadap Keputusan Pembelian. Management Analysis Journal, 5(4), 281-288.

Deisy, M., Lapian, J., \& Mandagie, Y. (2018). Analisis Citra Merek, Harga Produk dan Kualitas terhadap Keputusan Pembelian Handphone Samsung Pada Seluruh Gerai-Gerai Seluler di IT Center Manado. Jurnal Riset Ekonomi, Manajemen, Bisnis Dan Akuntansi, 6(4), 2288-2297.

Faroh, W. N. (2017). Analisa Pengaruh Harga, Promosi, dan Pelayanan terhadap Keputusan Pembelian. Journal Ilmiah Prodi Manajemen, 4(2), 3-24.

Fatmaningrum, S. R., Susanto, \& Fadhilah, M. (2020). Pengaruh Kualitas Produk dan Citra Merek terhadap Keputusan Pembelian Minuman Frestea. Jurnal Ilmiah Manajemen, Ekonomi Dan Akuntansi, 4(1), 176-188.

Fatmawati, N., \& Soliha, E. (2017). Kualitas Produk, Citra Merek dan Persepsi Harga terhadap Proses Keputusan Pembelian Konsumen Sepeda Motor Matic "Honda." Jurnal Manajemen Teori Dan Terapan, 10(1), 1-20.

Febriani, R. R., \& Sudaryanto, B. (2018). Pengaruh Brand Image dan Kualitas Layanan 
terhadap Kepercayaan dan Keputusan Pembelian pada Toko Online (Studi pada Konsumen OLX.co.id di Kota Semarang). Diponegoro Journal of Management, $7(2), 1-11$.

Fianto, A. Y. A., Hadiwidjojo, D., Aisjah, S., \& Solimun. (2014). The Influence of Brand Image on Purchase Behaviour Through Brand Trust. Business Management and Strategy, 5(2), 58-76.

Ghozali, I. (2018). Aplikasi Analisis Multivariat dengan Program IBM SPSS 25. Semarang: Badan Penerbit-Undip.

Habibah, Hamdani, I., \& Lisnawati, S. (2018). Pengaruh Brand Image dan Celebrity Endorser terhadap Keputusan Pembelian Produk Kosmetik Wardah (Studi pada Perempuan Muslim di Kota Bogor). Iqtishoduna, 7(2), 233-261.

Hendro, C. R., \& Hidayat, W. (2018). Pengaruh Kualitas Produk, Harga dan Citra Merek terhadap Keputusan Pembelian Konsumen Handphone Merek Iphone Kota Semarang. Jurnal Ilmu Administrasi Bisnis, 7(4), 177-184.

https://www.topbrand-award.com, diakses pada tanggal 13 Oktober 2020.

Hustić, I., \& Gregurec, I. (2015). The Influence of Price on Customer's Purchase Decision. Central European Conference on Information and Intelligent Systems, 27-32.

Indah, D. R., Afalia, I., \& Maulida, Z. (2020). Pengaruh Citra Merek, Kualitas Produk dan Harga terhadap Keputusan Pembelian Produk Hand and Body Lotion Vaseline (Studi Kasus pada Mahasiswa Universitas Samudra). Jurnal Samudra Ekonomi Dan Bisnis, 11(1), 83-94.

Istiyanto, B., \& Nugroho, L. (2017). Analisis Pengaruh Brand Image, Harga, dan Kualitas Produk terhadap Keputusan Pembelian Mobil (Studi Kasus Mobil LCGC di Surakarta). Eksis: Jurnal Riset Ekonomi Dan Bisnis, 12(1), 1-8.

Kasanti, N., Wijaya, A., \& Suandry. (2019). Pengaruh Harga dan Kualitas Produk terhadap Keputusan Pembelian Produk Safety Merek Proguard pada PT AIM Safety Indonesia. Asian Journal of Innovation and Entrepreneurship, 4(1), 4351.

Kotler, P., \& Armstrong, G. (2008). Prinsip-Prinsip Pemasaran. Jakarta: Erlangga.

Kotler, P., \& Keller, K. L. (2009). Manajemen Pemasaran. Jakarta: PT. Gelora Aksara Pratama.

Li, X. G., Wang, X., \& Cai, Y. J. (2011). Corporate-, Product-, and User-Image Dimensions and Purchase Intentions: The Mediating Role of Cognitive and Affective Attitudes. Journal of Computers, 6(9), 1875-1879.

Lubis, D. I. D., \& Hidayat, R. (2017). Pengaruh Citra Merek dan Harga terhadap Keputusan Pembelian pada Sekolah Tinggi Ilmu Manajemen Sukma Medan. Jurnal Ilmu Manajemen, 5(1), 15-24.

Mahmudah, I. S., \& Tiarawati, M. (2014). Pengaruh Kualitas Produk, Citra Merek, dan Harga terhadap Keputusan Pembelian Pond's Flawless White Indah. BISMA: Jurnal Bisnis Dan Manajemen, 6(2), 98-105.

Mandey, J. B. (2013). Promosi, Distribusi, Harga Pengaruhnya terhadap Keputusan Pembelian Rokok Surya Promild. Jurnal Riset Ekonomi, Manajemen, Bisnis Dan Akuntansi, 1(4), 95-104.

Mulyono, H. (2016). Brand Awareness and Brand Image of Decision Making on University. Jurnal Manajemen Dan Kewirausahaan, 18(2), 163-173. 
Nasution, A. E., Putri, L. P., \& Lesmana, M. T. (2019). Analisis Pengaruh Harga, Promosi, Kepercayaan dan Karakteristik Konsumen terhadap Keputusan Pembelian Konsumen Pada 212 Mart di Kota Medan. Proseding Seminar Nasional Kewirausahaan, 1(1), 194-199.

Novansa, H., \& Ali, H. (2017). Purchase Decision Model: Analysis of Brand Image, Brand Awareness and Price (Case Study SMECO Indonesia SME Products). Saudi Journal of Humanities and Social Sciences, 2(8), 621-632.

Puspita, S. D., Taslim, \& Fitriani, A. (2015). Pengaruh Harga, Kualitas Produk, dan Citra Merek terhadap Keputusan Pembelian Yoghurt (Survey pada Konsumen Yoghurt Youjell PT. Insan Muda Berdikari). Students E-Journals, 4(1).

Razak, I., Nirwanto, N., \& Triatmanto, B. (2016). The Impact of Product Quality and Price on Customer Statisfaction with the Mediator of Customer Value. Journal of Marketing and Consumer Research, 30, 59-68.

Rusman, T. (2015). Statistika Penelitian: Aplikasinya dengan SPSS. Yogyakarta: Graha Ilmu.

Sabrina, N. A. P., Elpawati, \& Nugraha, A. T. (2018). Analisis Pengaruh Citra Merek, Kualitas Produk, Harga Dan Diferensiasi Produk terhadap Keputusan Pembelian Pizza Hut di Jakarta Barat. Jurnal Agribisnis, 12(2), 148-156.

Sallam, M. A. (2016). The Impact of Brand Image and Corporate Branding on Consumer's Choice: The Role of Brand Equity. International Journal of Marketing Studies, 8(1), 98-106.

Sarjita. (2019). Pengaruh Promosi, Harga Dan Kualitas Produk terhadap Keputusan Pembelian. JBMA, 4(2), 80-93.

Shinta, A. (2011). Manajemen Pemasaran. Malang: UB Press.

Sitanggang, F., Sidebang, A., \& Mirza, D. F. (2020). Pengaruh Harga, Promosi, dan Kualitas Produk terhadap Keputusan Pembelian Ban Sepeda Motor Merek Swallow pada PT. Industri Karet Deli Medan. Tijarah, 1(19), 135-142.

Sudaryanto, S., Subagio, N. A., Awaliyah, I. N., Wulandari, D., \& Hanim, A. (2019). Influence of Brand Image, Price and Promotion on Consumer's Buying Decision of Fast Moving Consumer's Goods with Culture as a Moderating Variable in Basmallah Retail Store in Indonesia. International Journal of Scientific and Technology Research, 8(3), 85-92.

Sugiyono. (2019). Metode Penelitian Kuantitatif Kualitatif dan R\&D. Edisi Kedua. Bandung: Alfabeta.

Suliyanto. (2011). Ekonometrika Terapan: Teori \& Aplikasi dengan SPSS. Yogyakarta: Andi Offset.

Supriyadi, Fristin, Y., \& Indra, G. K. . (2016). Pengaruh Kualitas Produk dan Brand Image terhadap Keputusan Pembelian (Studi pada Mahasiswa Pengguna Produk Sepatu Merek Converse di Fisip Universitas Merdeka Malang). Jurnal Bisnis Dan Manajemen, 3(1), 135-144.

Tjiptono, F. (2008). Strategi Pemasaran. Yogyakarta: Andi Offset.

Wicaksono, D. A., Sumarsono, H., \& Santoso, A. (2019). Pengaruh Citra Merek (Brand Image), Kualitas Produk, dan Desain Produk terhadap Keputusan Pembelian Pada Produk Batik Mukti. ISOQUANT: Jurnal Ekonomi, Manajemen Dan Akuntansi, 3(1), 81-89.

Widjayanti, L., \& Suprihhadi, H. (2018). Pengaruh Kualitas Produk, Harga, dan Citra 
Merek terhadap Keputusan Pembelian. Jurnal Ilmu Dan Riset Manajemen, 7(11), 1-17.

Yazia, V. (2014). Pengaruh Kualitas Produk, Harga dan Iklan terhadap Keputusan Pembelian Handphone Blackberry (Studi Kasus Blackberry Center Veteran Padang). Journal of Economic and Economic Education, 2(2), 165-173.

Yuliardi, R., \& Nuraeni, Z. (2017). Statistika Penelitian Plus Titorial SPSS. Edisi Pertama. Yogyakarta: Innosain. 